\title{
Uruguay Round Agreement: The Interface Between Anti- Dumping and Competition
}

\section{Kishwar Khan and Sarwat Aftab ${ }^{1}$}

All the provisions of the Uruguay Round Agreements have a bearing upon competition policy, since the international framework governing trade determines the extent of competition in the national markets. Apart from the fundamental provisions of GATT Articles I (MFN treatment), III (National Treatment) and $\mathrm{X}$ (Transparency), there are numerous specific WTO provisions which are relevant in varying degrees to competition ${ }^{2}$

- GATT Article VI and the WTO Agreement on Antidumping which involves concept of injury, treatment of price discrimination, public interest, etc;

- GATT Article XVI and the WTO Agreement on Subsidies and Countervailing Measures such as concept of injury;

- Agreement on TRIMs; requiring the elimination of deletion programme and local content requirements;

- Agreement on TRIPs involving anti-competitive practices in contractual licenses, etc.

On the one hand, the consecutive multilateral trade talks at the WTO have reduced tariffs and trade barriers between member countries. But with the fall in the traditional trade policy tools, a rise in the new forms of protection has emerged. One important distinction between the traditional protection and the new forms of trade protection is that the latter are generally felt to be more selective and less transparent. Especially the use of antidumping measures, atleast in part, have replaced the tariffs and VERs.

The preparations for the Seattle Ministerial Conference indicated that many countries including Japan, Korea, Hong Kong, etc. were to argue for opening up WTO Anti-dumping (AD) Agreement with respect to

${ }^{1}$ The authors work in the Monopoly Control Authority as Economist and Assistant Director respectively. The views expressed in the paper are of the authors and in no way relate to those of the Monopoly Control Authority.

${ }^{2}$ Indepth discussions regarding consistency between trade and competition rules; and also on the possibility of international rules is worked out by OECD, see (8) and (9) for details. 
competition-consistency ${ }^{3}$. The $\mathrm{AD}$ Agreement was discussed at the Seattle Conference held on December 1-3, 1999. Japan's view point on the AD Agreement was that its abusive use should be regarded as a disguised form of protectionism that nullifies tariff reductions. The improvement of the $\mathrm{AD}$ Agreement was considered as a lynchpin of the new round and this view was supported by many developing countries ${ }^{4}$. However, there was no concrete outcome of the Conference since the talks were suspended inconclusively. This does not necessarily mean that the issues raised in the Conference have now lost their significance, since this was not the first time that the Ministerial talks were suspended ${ }^{5}$.

This paper examines the $\mathrm{AD}$ Agreement with respect to implications for competition, combining both theoretical as well as practical issues. The first section gives an overview of the $\mathrm{AD}$ Agreement. The second section covers the relationship between AD Policy and Competition Policy (CP). Central concepts are also explored e.g., price discrimination, predation, injury, causality and minimum cause, etc. The third section gives a comparison of Competition and Anti-dumping legislation. The status of Pakistan's AD legislation is covered in the fourth section. The last section gives some specific suggestions and conclusions of the paper.

\section{An overview of the Article VI of GATT}

The Anti-Dumping Agreement elaborates the rules for applying the provisions of Article VI of the General Agreement and the Tokyo Round Code. It provides greater uniformity in the implementation of anti-dumping rules, protecting the interests of exporting countries, including developing countries. Anti-dumping measures and unilateral remedies which may be applied by a Member after an investigation and determination by that Member, in accordance with the provisions of the AD Agreement, that an imported product is "dumped" and that the dumped imports are causing material injury to a domestic industry producing the like product. The additional disciplines in the Agreement include: ${ }^{6}$

- more detailed methodology for calculating the dumping margin and, in general, stricter discipline on the data to be used for such a calculation;

\footnotetext{
${ }^{3}$ WTO website, Preparations for the Seattle Conference, various country contributions.

${ }^{4}$ WTO Briefing note on Ministerial Conference, WTO website, December 7, 1999.

${ }^{5}$ Other instances of talks suspension include the UR Mid-Term Review, Montreal December, 1988; Brussels Ministerial Meeting December 1990. Statement by WTO Director-General, Mike Moore. WTO website, Press Release, December 7, 1999.

${ }^{6}$ This section is based on the information contained in the Legal Texts (1) and from the WTO website.
} 
- more detailed requirements for the determination of injury, in particular, treat of injury;

- a definition of producers related to exporters or importers;

- a specification of a de minimis dumping margin and volume for terminating proceedings. Anti-dumping cases are to be terminated if the margin of dumping or the share of the volume of imports from particular countries in the importing market are below the specified threshold levels;

- stricter disciplines on the initiation and subsequent investigation, imposition of provisional measures and prices undertaking entered into by exporters;

- time limits on the duration of an investigation, the period within which refunds are to be provided and the duration of anti-dumping measures;

- increased transparency in the procedures to be followed by the investigating authorities and in the public notice;

- disciplines on the imposition of anti-dumping duties on exporters or producers who have not been investigated individually;

- an accelerated review for producers who did not export the product in question during the period of investigation;

- a review of anti-dumping measures by the authorities of the importing country; and

- a provision for domestic judicial review.

Under the $\mathrm{AD}$ Agreement, the investigating authorities must take due account of any difficulties experienced by interested parties, in particular small companies, in supplying the information requested.

\section{Relationship Between Anti-dumping (AD) Policy and Competition Policy (CP)}

$\mathrm{AD}$ policy aims at reducing the impact of an anti-competitive practice i.e., selling abroad for less than in the domestic market. Thus AD policy is, in a rather special sense, a part of the competition policy. CP is directed at actions taken in regard to the domestic market, and generally by the domestic firms. But the countries which have properly articulated CPs 
do address actions taken abroad by foreign-controlled and foreign-based companies, which have anti-competitive effects in the domestic market(11).

The question arises whether the $\mathrm{CP}$ and the law of a country could also cover the $\mathrm{AD}$ system, alongwith other measures against anti-competitive practices by foreign companies. More specifically, the issue is why one particular type of anti-competitive practice - price discrimination - should be dealt with under different rules, standards and tests when it is practised by exporters in other countries then if it is practiced by domestic firms.

In case, the $\mathrm{AD}$ system penalises price discrimination in import trade more severely than similar price discrimination in domestic commerce (under competition law), the $\mathrm{AD}$ system would therefore be more protectionist in nature. Due to this reason, its application would appear to be in breach of the National Treatment obligation of GATT Article III.

It is obvious that governments have to take some remedial action when there is a sharp increase in the volume of imports at unusually low prices, displacing domestic production. A government has, then, to determined whether the intolerable surge in imports is due to an essentially anti-competitive action by a foreign firm(s), or whether it reflects changes in the structure of production. In the first case, measures designed to offset the anti-competitive action may be appropriate; in the latter case, the government should focus on other adjustment measures to protect the labour force from displacement.

\section{Price discrimination, predation and injury}

$\mathrm{AD}$ laws are directed at international price discrimination. In this sense, there appears to be some resemblance between injury under AD laws and "primary line" injury under competition laws concerning price discrimination. In some countries, for example the US, the competition law makes a distinction between "primary line", "secondary line" and "tertiary line" injury. "Primary line" injury concerns injury to competitors of the firm while "secondary line" injury concerns injury to downstream firms. "Tertiary line" injury concerns injury to the customers (4).

For price discrimination claims in a domestic competition policy context, it must be shown to harm competition, not merely to harm particular competitors. Furthermore, in some jurisdictions the complaint of price discrimination is subject to defenses such as "meeting the competition", that is a competitor lowers his price in one area in order to compete with the lower prevailing price. There is no similar defense available in dumping cases. 
Predatory pricing is designed to exclude an equally or more efficient competitor from the market and thus is anti-competitive in nature. The $\mathrm{AD}$ provisions (i.e., the Agreement and national legislation) are not directed at predatory dumping, but at any dumping which causes injury or threatens injury to a domestic industry.

Under the WTO rules, the determination of injury is a separate inquiry from the determination of dumping margins. When injury cannot be proven, the analysis ends regardless of whether the existence of a dumping margin has been proven. The W'TO rules also provide that there "shall be immediate termination in cases where the authorities determine that the margin of dumping is de minimis (less than 2 per cent of the export price), or that the volume of the dumped imports (generally less than 3 per cent for any one country), actual or potential, or the injury, is negligible".

The GATT/WTO framework requires that authorities examine any known factors other than the dumped imports which at the same time are injuring the domestic industry, and injuries caused by these factors must not be attributed to dumped imports. Many countries believe that the concept of injury is separable - i.e., an industry can be suffering from various injuries, from various causes. It is worth noting that both the EU and Canada have legislative provisions to apply the "community interest rule" in an Ad case. This rule takes into account the interests of both the producers and the consumers.

The standing requirements for initiating a dumping investigation under the GATT - W'TO framework are more demanding for a complainant then is the case in competition proceedings. For a dumping case to proceed, there must be evidence that the complaint is made by domestic producers constituting more than 50 per cent of the domestic production of the like product. This requirements under competition laws are not so stringent. However, the parties need to demonstrate that they are potentially harmed by the alleged anti-competitive practices.

The $\mathrm{AD}$ investigations are subject to strict negotiated time schedules codified in WTO Agreements, whereas there is no such multilateral agreement and few domestic law requirements that limit the decisionmaking time in competition cases.

\section{Causality or minimum cause}

Causality means that the dumped imports must be shown to be the cause of a material injury to the domestic industry. The demonstration of a causal relationship between the dumped imports and the injury to the 
domestic industry is based on an examination of all relevant evidence before the authorities. Factors which may be relevant in this respect include the volume and prices of imports not sold at the dumping prices, contraction in demand or changes in the pattern of consumption, trade restrictive practices of and competition between the foreign domestic producers, developments in technology and the export performance and productivity of the domestic industry.

\section{Competition Consideration in AD Agreement}

The wording of $\mathrm{AD}$ Agreement appears to make it mandatory that domestic authorities, when investigating the impact of dumping, consider "trade restrictive practices of and competition between the foreign and domestic producers". This phrase is from Article 3.5. However, not all countries have taken all Agreement provisions into their domestic legislation. Accordingly, in domestic law in those countries there may be no requirement that the requirements of Article 3.5 be considered by the administrative authority. Clearly, there is one step that could be taken to bring CP considerations into Ad policy without changing international rules: all that appears to be required is that the existing Agreement provisions be properly implemented.

The Working Group on "Interaction Between Trade and Competition Policy" is discussing the possibilities of international competition regimes, but one thing should be clear: the creation of an international competition policy would not eliminate the need for $\mathrm{AD}$ laws because competition laws are designed to attack a different set of problems than $\mathrm{AD}$ laws. Antitrust laws can never be a substitute for Ad law because these two disciplines have different objectives and seek to remedy different practices.

It should be considered at this stage that the competition law is neither always fully developed nor is there international agreement on policy. This reflects the fact that within many countries there are sharp, and often highly politicised differences of views about the economic and legal rationale of CP. CP varies widely from one WTO member to another. Therefore, the possibilities of multilateral actions in either area should be worked out carefully.

\section{Antidumping and Competition Laws}

Competition laws focus primarily on consumer welfare and attempt to remedy price discrimination, predatory pricing or other anti-competitive practices by the private actors. AD laws focus on the interest of producers and their workers. 
Although competition and Ad legislations have different objectives there is a direct link between the two: when a foreign government fails to enact or enforce competition legislation (CL) in its home market, thereby giving its producers an artificial competitive advantage, those producers may engage in injurious dumping in other markets. Protection by the government may also take the form of tariffs and non-tariff barriers (NTBs). NTBs include state-sponsorship of domestic distribution regimes, government pricing policies etc. A government may protect a domestic industry by simultaneously placing limits on domestic competition and creating barriers against foreign competition. It may directly subsidise a domestic industry via provisions of grants or by imposing price control, or indirectly by arranging with a domestic producer to sell its goods to a state trading company at an artificially high level, with the trading company then selling the goods abroad at artificially low prices. Such measures give these companies advantages in the market place that do not arise from greater efficiency, thereby leading to serious mis-allocations of resources ${ }^{7}$.

The $\mathrm{AD}$ laws are based on the assumption that there is inherent value in protecting workers and their companies from injury by other companies that are not manufacturing products more efficiently. In the short-term dumping improves the well-being of domestic consumers in the form of lower prices. The long term picture is not so positive as the injury caused to domestic producers may cause workers to lose their jobs, and even the most efficient factories to close, causing distortionary ripples in the economy. Faced with less competition those companies that remain will raise prices. The pace of innovation slackens, and ultimately, consumers pay the price with inferior, higher-priced products (10).

Several governments have begun to employ anti-dumping legislations since the UR entered into force. Singapore replealed outmoded AD laws in 1996. China enacted its first AD legislation in 1997. Of course, China's application of its Ad law will not be subject to review by the DSU unless and until that nation enters the WTO.

$\mathrm{AD}$ legislation vary from country to country. The EU AD legislation deviates from the US in a number of respects: first, the level of Ad protection in the EU is limited to the injury margin provided it is smaller than the dumping margins. In the US, the duty is always based on the dumping margin which results in higher duty levels. Second, the EU besides duties often imposes price undertakings which can be compared to 'voluntary price restraints'. Third, duties in the EU are levied prospectively,

\footnotetext{
${ }^{7}$ Frederic Jenney (12) provides an informative discussion on the international dimension of competition policy.
} 
this means only after positive dumping and injury findings. The US has a retrospective duty system, where a bond has to be deposited before the outcome of an investigation is known but which is paid back in case the alleged dumper is not found guilty. A refund of duty revenue in the EU is possible in principle but in practice very difficult to obtain. Refunds have only occurred in very few cases and may take upto ten years after the period of protection. Interest over this period is never refunded ${ }^{8}$. Finally, the EU 'Sunset clause' stipulates that $\mathrm{AD}$ measures automatically lapse after five years, in contrast to the US, where measures only lapse if the foreign importer shows that dumping has stopped (6).

In the past few years, developing countries have increasingly been using antidumping laws. Developing countries have initiated dumping cases against both developed and developing countries ${ }^{9}$. Interestingly, atleast five developing countries (India, Egypt, Indonesia, Malaysia and Pakistan) have criticised the developing country provision of the WTO AD Agreement. This provision states that special regard must be given by developed countries to the special situation of developing countries when considering the application of $\mathrm{AD}$ measures. The provision further provides that "possibilities of constructive remedies provided for by this Agreement shall be explored before applying $\mathrm{AD}$ duties where they would affect the essential interests of developing country members". These countries complained that this provision needs to be turned into concrete steps that can be implemented. Interestingly, India has become a significant user of its $\mathrm{AD}$ law, including against developing countries. In 1997, $240 \mathrm{AD}$ investigations were initiated world wide. Some countries that had been strong critics of the Ad laws are now applying them with frequency.

\section{Status of AD Law in Pakistan}

Presently, the draft AD legislation is in the Senate for approval. The law provides for all the relevant important definitions. The procedure would be such that the application for dumped imports will be received and processed by the National Tariff Commission for preliminary investigations ${ }^{10}$. The Commission then, will pass on its recommendations to the Government for investigation. An appeal could be filed with the Customs Tribunal against the government's decision. The matter if disputed, would then be referred to the DSU at the WTO. Industries which have alleged dumping of imports in Pakistan include chemicals, tin plates, toys, polyester staple fiber,

${ }^{8}$ Vanden Bussche, Linda Springael and Jozef Konings in 'Import diversion under European Antidumping Policy’, National Bureau of Economic Research, September 1999.

${ }^{9}$ For details on WTO dispute cases, see (3).

${ }^{10}$ Source is National Tariff Commission. 
etc. however, no case could have been initiated by Pakistan due to nonexistence of a legislation.

\section{Conclusions and Suggestions}

A number of WTO members, including developing country members, share the concerns about the adequacy and the fair implementation of rules governing trade remedies such as $\mathrm{AD}$ measures. $\mathrm{AD}$ measures have been invoked with increased frequency and by an increasing number of measures. Easy access to and increased dependence on such trade remedies will nullify the benefits of tariff reductions. Developing countries, like Pakistan are worried not just about the frivolous complaints but also the repeated $\mathrm{AD}$ charges against the same products. It is noteworthy that new investigations are initiated against the same products almost immediately after the conclusion of an earlier investigation. Moreover, when it is proved that $\mathrm{AD}$ duties have been imposed without sufficient justification and evidence, the country which has acted unjustly to blunt competition is not penalised and made to reimburse the affected exporters the duties collected from the $\mathrm{AD}$ moves. The W'TO is silent on the issue, though it needs to be addressed urgently.

While an $\mathrm{AD}$ measure is one of legitimate trade remedies permitted under current WTO regimes, due attention should be paid to avoid its abuse for protectionist purposes. Serious problems exist even if final duties are not imposed, such as the $\mathrm{AD}$ investigations entail huge burdens on respondents, and that restrictive effects on the trade of the countries in question are significant. The reasons of the above mentioned problems are, inter alia; (i) lack of appropriate implementation of the $\mathrm{AD}$ Agreement due to its ambiguous provisions; and (ii) insufficient disciplines in the relevant provisions of the $\mathrm{AD}$ Agreement to avoid inappropriate $\mathrm{AD}$ measures. As a pre-requisite of appropriate implementation, it is essential to eliminate ambiguities in relevant Articles in the Agreement, thus clarifying standards for judgement entrusted to the investigating authorities. This can prevent arbitrary usage and has the advantage of facilitating implementation when measures are truly necessary. Clarification of procedures and standards can contribute to preventing unjustified petitions or investigations as well.

Some specific recommendations for Pakistan are as follows:

- There is an urgent need to have domestic $\mathrm{AD}$ legislation at the earliest.

- The AD Agreement does not adequately address the potential for the abuse of $\mathrm{AD}$ proceedings to harass exporters. There is a need to 
eliminate ambiguities in the relevant articles of the AD Agreement. These issues should be raised in the post-Seattle Ministerial Conference discussions.

- The Pakistan Government and private industry need to join hands to counter the charges of dumping being levied against different subsectors of the textiles industry because the cost of participating in $\mathrm{AD}$ investigations is expensive and cumbersome.

- There is a need to develop expertise within the country, by tapping the handful of Pakistani professionals with the requisite experience to counter the growing menace of $\mathrm{AD}$ claims being prepared against Pakistan by the industrialised economies.

- The Agreement on $\mathrm{AD}$ unfairly restricts the role of Dispute Settlement (DS) Panel. According to the Article 17.6 of the Agreement which says "in its assessment of the facts of the matter, the Panel shall determine whether the authorities' establishment of the facts was proper and whether their evaluation of those facts was unbiased and objective. If the establishment of the facts was proper and the evaluation was unbiased and objective, even though the Panel might have reached a different conclusion, the evaluation shall not be overturned". This means that if there are two or more interpretations of any provision, the interpretation of the country imposing the penalties will prevail, even if the Panel disagrees with this interpretation. The DS Panel for Ad is only empowered to assess whether the evaluation of the facts by the party imposing dumping duties was carried out in an unbiased and objective manner. Such a provision contrasts sharply with the powers enjoyed by the Panels under other articles of the agreements. These selective methods and the discretion they provide to those initiating the Ad cases need to be reformed. Without these reforms, the WTO will fail to function independently as a neutral body in determining the veracity of $\mathrm{AD}$ claims. The issues needs to be raised jointly by the developing countries. 


\section{References}

WTO, The Results of the Uruguay Round of Multilateral Trade Negotiations - The Legal Texts, Geneva, 1995.

Shahid Kardar, Curse of Anti-dumping Charges, The News article, September 24, 1999.

Overview of the State - of - Play of WTO Disputes, July 30, 1999. WTO website.

Rodney de C. Grey, The relationship between Anti-dumping Policy and Competition Policy, UNCTAD, May 31, 1999.

Richard A. Posner, Antitrust Law/ An Economic Perspective, Chicago University Press, 1976.

Vanden Bussche, Jozef Konings and Linda Springael, Import Diversion Under European Antidumping Policy, NBER Working Paper 7340, September, 1999.

Stiglitz J., Two Principles for the Next Round or, How to Bring Developing Countries in From the Cold, Geneva, 1999.

OECD, Competition Policy: What Chance for International Rules? Note by the Editor. Paris, 29-30 June, 1999.

OECD, Joint Group on Trade and Competition, Consistencies Between Trade and Competition Policies, Paris, 29-30 June, 1999.

Jorge Miranda, Anti-dumping and Anti-Trust: Distant Siblings Who Need Not be Unfriendly, WTO/ADB Seminar on Trade Remedies and Competition Policy, Thailand, 11-13 May, 1999.

UNCTAD, The Scope, Coverage and Enforcement of Competition Laws and Policies and Analysis of the Provisions of the Uruguay Round Agreements Relevant to Competition Policy, Including their Implications for Developing and Other Countries, 19996.

Frederic Jenny, in 'Competition Policy in a Global Economy', The Interface between Competition Policy and Trade, Investment and Economic Development, November, 1997. 